\title{
Review on the Effect of Seed Source and Size on Grain Yield of Bread Wheat (Tritium Aestivum L.)
}

\section{Gadisa A* \\ Kulumsa Agricultural Research Center, Ethiopia}

*Corresponding author: Gadisa Alemu, Kulumsa Agricultural Research Center, Assela, Ethiopia, Tel: +251910952641; Email: gadalemu@gmail.com

\section{Review article}

Volume 3 Issue 1

Received Date: October 22, 2018

Published Date: January 07, 2019

DOI: $10.23880 /$ jenr-16000155

\section{Abstract}

Wheat (Tritium aestivum L.) is the most important crop and among the major three cereal crops that provides 20 percent of the total energy requirement in human food. It is a major crop contributing importantly to the nutrient supply of the global population and has the highest content of protein of all the staple cereals and contains essential minerals, vitamins, and lipids. It shows wide adaptation to diverse agro-ecological conditions and cropping technologies. The productivity of the crop remains low (2.4 tons ha-1) in the Ethiopia as compared to the world average yield (3.19 tons ha-1). The low yield per hectare is attributed to many factors, such as seed source, unavailability of quality seed, use of poor quality seeds, inappropriate seed size and seed rate are some of the factors. Seed source influenced growth and yield during the growing season but the response depended on seed size and variety. Seed quality is very important to optimum growth and yield production in farm which influenced by many factors such as genetic characteristics, viability, germination percent, vigor, moisture content, storage conditions, survival ability and seed health. High quality seed is important to ensure maximum seed germination and seedling vigor, which is turn is instrumental in achieving maximum yield. poorer quality seeds show low viability, reduced germination and emergence rates, poor tolerance to sub optimal conditions and low seedling growth rates. The seed quality is also reflected in the final growth, maturity of plants, their uniformity and stability of yield. Seed size is an important physical indicator of seed related to yield, market grade factors and harvest efficiency. Seed size was the trait that was most consistently associated with yields. Seed size was the most consistent seed trait that influenced growth and yield. Grain yield of wheat significantly increased by increasing seed size. The use of high quality seed and large seed size increase the grain yield of bread wheat.

Keywords: Quality seed; High quality; Seed size

\section{Introduction}

Wheat (Tritium aestivum L.) is the most important crop and among the major three cereal crops that provides 20 percent of the total energy requirement in human food [1]. It is a major crop contributing importantly to the nutrient supply of the global population and also a very versatile crop. It shows wide 
adaptation to diverse agro-ecological conditions and cropping technologies [2]. It is major source of food grain and high adaptation of this crop as well as its diverse consumptions in the human nutrition lead to present, it as the most important cereal in the world, especially in developing countries [3].

World wheat production increased dramatically from 1951-1990, mainly due to an increase in grain yield per hectare rather than an increase in production area. Consumption worldwide has also increased rapidly since early 1960 's. Wheat consumption in developing countries rose 35 percent during the period 1963-1976. A recent analysis by Jayne, et al. [4] has also confirmed rapid growth in wheat consumption as a consequence of urbanization, rising incomes, and dietary diversification in Eastern and Southern Africa. In Eastern Africa, Ethiopia ranks first both in terms of area harvested $(1,627,647 \mathrm{ha})$ and total wheat production $(3,434,706$ tons $)$ reported by FAOSTAT 2013 [5]. In 2013/2014 cropping season, out of the total grain crop area, $79.38 \%(9,848,745.96$ ha) was under cereals. From this area, wheat took up $13.52 \%$ $(1,677,486.33 \mathrm{ha})$ of the grain crop area. Among cereals, wheat accounts for $15.60 \%(3,925,194$ tons) grain [6]. However, the productivity of the crop remains low (2.4 tons ha-1) in the country as compared to the world average yield (3.19 tons ha-1) FAOSTAT 2013 [5]. The low yield per hectare is attributed to many factors, such as unavailability of quality seed for varieties that are high yielding as well as adapted to wide range of agroecologies of the country and use of poor quality seeds (poor quality of farmer saved seeds) are some of the factors. Poor quality seed results in poor germination and poor crop stands at farm and become a significant factor affecting wheat productivity.

Seed size, as a characteristic of seed quality, influences seedling growth and establishment. Studies of the relationship between seed size and early growth have been reported since early this century. Seed size is an important physical indicator of seed related to yield, market grade factors and harvest efficiency. A wide array of different effects of seed size has been reported for seed germination, emergence and related agronomical aspects in many crop species. However, these results varied widely between species. In wheat, seed size is positively correlated with seed vigor: larger seeds tend to produce more vigorous seedlings. Rukavina, et al. [7] found that low-vigor spring wheat seed produced lower crop stand and lower grain yields.

Proper and uniform stand establishment are the key factors for successful crop production in all cropping systems. To ensure such stand, even under adverse conditions, high quality seed must be planted. In wheat, Tanner and Sahle [8] estimated that the use of quality seed has significantly increased crop productivity by $15-$ $25 \%$. Varying seedling vigor determinants have been correlated to find better selection criteria for crop stand establishment in wheat fields. The low yield might be due to the use of farm saved poor quality seeds of local cultivars, in appropriate seed rate and size. Therefore, it is paramount to conduct research to evaluate the productivity of wheat varieties produced from different seed sources including farm saved seeds under different seed size. Thus, the objectives of this review was to review the effect of seed sources and seed size of bread wheat on grain yield and seed quality of different sources and its associations with yield of bread wheat.

\section{Literature Review}

\section{Wheat Production in Ethiopia}

Ethiopia ranks second in sub-Saharan Africa in total wheat area and production. It is one of the most important cereal crops cultivated in the country Birhanu [9]. The Ethiopian highlands are considered a center of diversity for wheat and it has been cultivated in this region for several millennia with little change in farm implements and farming practices among small holder farmers. Wheat is mainly cultivated in the south eastern, central, south and north western highlands at altitudes ranging from 1500-2800 m.a.s.l. primarily under rain-fed conditions.

Wheat production in Ethiopia ranks fourth in area coverage surpassed only by tef (Eragrostis tef), maize (Zea mays), and sorghum (Sorghum bicolor) and it is the third largest crop in total production [10]. The relatively low mean yield may be partially attributed to the low level of adoption of improved varieties and improved management techniques [11]. Ethiopia imports more wheat than any other crop at 1.74 million tons annually and consumption is increasing much faster than production with an annual population growth rate of three percent [12]. Increasing wheat production is important to the economic stability and food security of Ethiopia. Utilization wise, wheat is used for the manufacture of flour for different purposes. Bread, biscuits and pasta products such as macaroni, spaghetti and noodles are some of the industrial products. Bread wheat is known to be a major source of energy and protein. Traditionally the crop is used for making Dabo, Dabokolo, Genfo, Kinche and other types of foods. The 
straw is good source for animal feed and is also used for hatching roofs [13].

\section{Seed Sources}

Seed source influenced growth and yield during the growing season but the response depended on seed size and variety. The source of seed is can also be important since location influences seed nutrient content. The seed source has significant effect on seedling dry weight. Alemayehu [14] was reported that the number of tillers were significantly affected by main effect of variety, seed source and seed rate. Interaction effect of variety and seed source has highly significant effect on number of tillers per $1 \mathrm{~m}$ length. The influence of seed source on seed quality attributes, such as germination percentage, rate of germination, seedling root length and seedling fresh weight, was significant under laboratory conditions [14].

Farmers in Ethiopia can obtain seed from formal and informal sources. The formal seed source is a system composed of institutional and organizational arrangements consisting of all enterprises and organizations that are involved in the flow of modern varieties from the Agricultural Research Centers to farming communities, which include variety development, release and registration, seed multiplication and processing, seed marketing and distribution and seed quality control and certification. The informal seed source under Ethiopian context is defined as a system of seed production and distribution along with the different actors where there is no legal certification in the process [15]. In Ethiopia, the informal (either self-saved seed or farmer-to-farmer seed exchange, cooperative based seed multiplication and distribution, NGO based seed multiplication and distribution) seed source is the dominant for seed supply which accounts for $90 \%$ of the seed used by smallholder farmers [16].

Five key features distinguish the informal seed system from the formal seed system. The informal system is traditional, semi-structured, operate at the individual community level, uses a wide range of exchange mechanisms, and usually deal with small quantities of seeds. It is demanded by farmers and may depend upon indigenous knowledge of plant and seed selection, sourcing, retaining and management as well as local diffusion mechanism.

\section{Seed Quality}

Seed quality is defined as standard of excellence in certain characteristics and/or attributes that will determine the performance of the seed when sown or stored [17]. Seed quality describes the potential performance of a seed lot. Trueness to variety; the presence of inert matter, seed of other crops, or weed seed; germination percentage; vigor; appearance; and freedom from disease are important aspects of seed quality. High-quality seed lots should meet minimum standards for each of these characteristics. High quality seed is the key to successful agriculture [18]. For achieving optimum growth and yield production, the basic requirement of farming is to obtain quality seed [19]. Good quality seed can increase yields by $5-20 \%$. The extent of this increase is directly proportional to the quality of seed that is being sown. According to Akbari, et al. [19] reported seed quality is very important to optimum growth and yield production in farm which influenced by many factors such as genetic characteristics, viability, germination percent, vigor, moisture content, storage conditions, survival ability and seed health, but their most important is germination percent and vigor. High quality seed is important to ensure maximum seed germination and seedling vigor, which is turn is instrumental in achieving maximum yield. Seed quality determines the optimum growth and yield production in the farm which is influenced by many factors such as genetic characteristics, viability, germination percentage, vigor, moisture content, storage conditions, survival ability and seed health [19].

The seed quality is also reflected in the final growth, maturity of plants, their uniformity and stability of yield. For seed to play a catalytic role, it should reach farmers in a good quality state, i.e. high genetic purity and identity, as well as high physical, physiological and health quality [20]. If the seed lots possess high genetic purity and high germination percentage and a minimum of inert matter, weed and other crop seeds, free from diseases and meets the certification standards, is said to have high quality.

In general, poorer quality seeds show low viability, reduced germination and emergence rates, poor tolerance to sub optimal conditions and low seedling growth rates. If seedling emergence is inadequate, crop yield will be reduced and in most situations no amount of efforts and expenses later on crop development can be compensated for these effects. There is a clear relationship existing between crop density and yield with yield increasing asymptotically as the density increases. Therefore the number of seedlings emerging does not only affect total crop yield, but the size of individual plant and the graded yields, time taken to reach maturity and uniformity of the plant at maturity [21]. 


\section{Journal of Ecology \& Natural Resources}

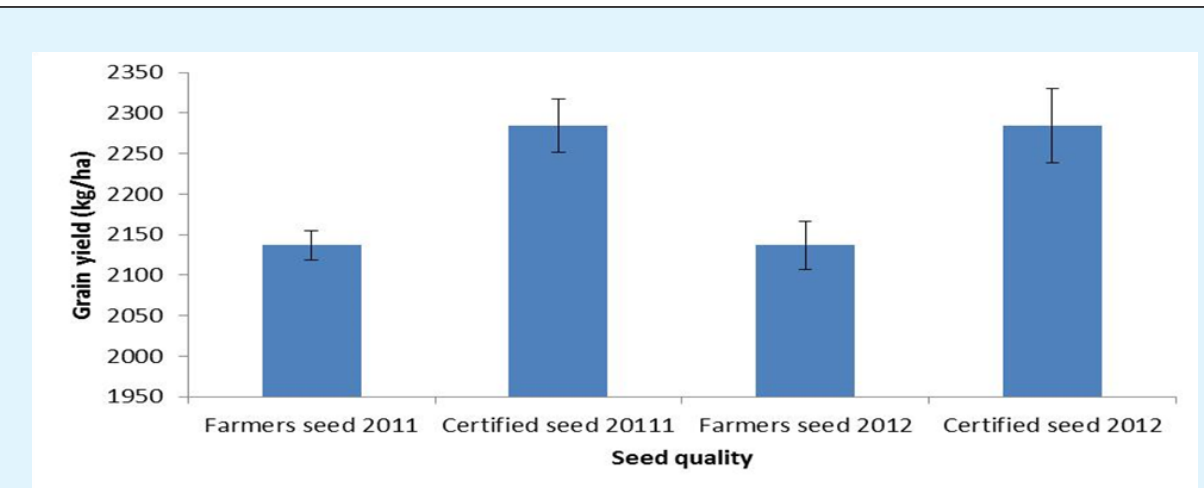

Figure 1: Effect of seed quality on grain yield [22].

\section{Seed Size}

Seed size is an important physical indicator of seed related to yield, market grade factors and harvest efficiency and important parameter, which influences the germination, growth and biomass of the nursery seedlings and that trend leads to the future crop. Kumar and Seth [23] observed that seed size affected the seed yield significantly. A wide array of different effects of seed size has been reported for seed germination, emergence and related agronomical aspects in many crop species. However, these results varied widely between species. With increased seed size higher germination and emergence were determined.

Seed size was the trait that was most consistently associated with yields. Grain yield depended on the seed used and it decreased with an increase in the size of seeds. In wheat, seed size is positively correlated with seed vigor: larger seeds tend to produce more vigorous seedlings. Grain yield of wheat significantly increased by increasing seed size. Variation in seed size within a seed lot affected neither seedling emergence, plant fertility, nor grain yield per plot. Gan and stobbe [24] was suggested that smallseeded plants produced $2-44 \%$ less tiller grain yield than neighboring large-seeded plants. Grain yield with smallest size $(2-2.2 \mathrm{~mm})$ was significantly lower than larger seed sizes [25]. Stougaard and Xue [26] who reported that use of larger seed sizes improved grain yields by $18 \%$ and the use of small seeds reduced yield by $16 \%$ in wheat. In other crops, similarly by Bicer [27] reported that in chickpea and lentil found that plants from large seeds yielded $6 \%$ more than medium seeds and $10 \%$ more than mixed seeds. The large seeded plants compensated for the yield loss by producing a $10 \%$ higher tiller grain yield plants grown from the uniform large-seed wheat.
Larger seeds of spring wheat produced higher yields than smaller seeds under late-sown conditions, but not under optimum management conditions. Similarly, Rukavina, et al. [7] found that low-vigor spring wheat seed produced lower crop stand and lower grain yields. Vigorous growth associated with large seed or with varieties promoted early growth and yield.

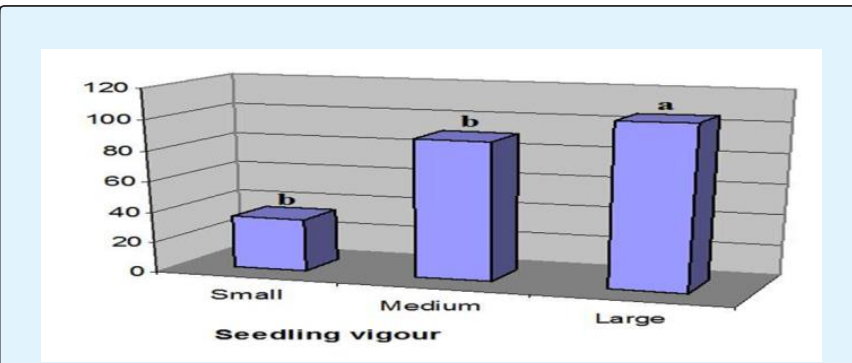

Figure 2: Effect of seed size on seedling vigour in wheat [28].

\section{Effect of large seed on grain yield of wheat}

Larger seeds of spring wheat produced higher yields than smaller seeds under late-sown conditions but not under optimum management conditions. In wheat, seed size not only influence emergence and establishment but also affected yield components and ultimately grain yield. Simmone, et al. [29] reported that size of seed has a strong influence on germination as well as growth and biomass increment of a plant. With increasing seed size spike production and density, number of tillers, main stem length, thousand kernel mass, test mass, seed vigor and yield increased, maturity was advanced and seed moisture content at harvest decreased in Croatian spring malting barleys [7]. 
Use of large seed size and increased seeding rates can improve wheat competitiveness and provide an effective means to reduce wild oat biomass and seed production. Kumar and Seth [23] observed that seed size affected the seed yield significantly. Plants derived from large seed appear to have greater vigour and are able to acquire a larger share of plant growth factors relative to plants derived from small seed. In similar study was reported that use of larger seed sizes improved grain yields by $18 \%$ and the use of small seeds reduced yield by $16 \%$ in wheat [30]. Stougaard and Xue [30] opined that $18 \%$ of increased yield could be obtained by larger seeds in wheat. Large seeds have more food storage for embryo growth and development which lead to vigorous growth of the seedling before weeds can emerge and create competition. Lima, et al. [31] noted that crop growth rate at the beginning of the growth cycle was higher in plants originating from large seeds. Khurana and Singh [32] who noted that seed size variations affected leaf area, large seeds producing greater leaf area.

Stobbe, et al. [33] reported that crops grown from large kernels consistently yielded higher than crops grown from small kernels of the same cultivar, for both wheat (Triticum aestivum L.) and barley (Hordeum vulgare). Adejare [34] reported that large seed size of elite maize had higher seed quality and higher seed yield compared to other medium and small sizes. High grain yield was obtained with the $7 \mathrm{~mm}$ seed size seed size of 6 and $6.5 \mathrm{~mm}$ in corn [35].

\section{Effect of medium seed and small size on grain yield wheat}

Abdul Raziq, et al. [36] determined that wheat sown with medium size of seed and small size seed followed a simultaneous decrease in wheat production and concluded that large size seed resulted in maximum grain yield (5294.30 kg ha-1) and yield decreased considerably when sowing was done with medium size and small size seed

Elliott, et al. [37] noted that small seeds produced seedlings with much less vigour. Dar, et al. [38] have mentioned that small seeds to medium sized ones produced better germination and seedling vigor than those of bigger ones. Smallest seed size had lowest emergence therefore, it is assumed that plants grown from small seed had less fertile tillers than those grown from large seed. Whereby, grain yield and biological yield decreased in smallest seed size. It is obvious that increase in biological yield by increasing seed size was related to higher seedling weight and weight of 100 plants were produced by larger seed sizes in wheat [25]. Adebisi, et al.
[39] reported that in tropical soybean lots with small seed size had maximum seed germination (97\%) and emergence (90\%) while those with large seed size produced the highest seed (88) per plant, pods (54) per plant and seed yield $(9.72 \mathrm{~g}$ ) per plant.

\section{Effect of seed size on wheat germination and seedling vigour}

The crop stand is mainly dependent of good germination of seed and germination is entirely dependent on the viability and quality of seed [40]. For achieving optimum growth and yield production, the basic requirement of farming is to obtain quality seed [19]. Similarly, seed size is an indicator of seed related to yield, market grade factors and harvest efficiency. The crop sown with large size seeds showed remarkably better agronomic performance with $95.29 \%$ germination, 96.61 $\mathrm{cm}$ plant height, 6.40 tillers plant-1, $11.44 \mathrm{~cm}$ spike length, 42.65 grains spike- $1,42.80$ g seed index (g), $10241 \mathrm{~kg}$ ha1 biological yield and $4857.10 \mathrm{~kg}$ ha-1 grain yield [36]. In wheat, seed size is positively correlated with seed vigor, larger seeds tend to produce more vigorous seedlings [41]. Germination rate and seedling vigour index values increased with the increase of seed size suggesting the selection of larger seeds for good stand establishment in rice. In wheat, seed size is positively correlated with seed vigour: larger seeds tend to produce more vigorous seedlings [42]. Generally, bigger seeds germinate quicker and would take lesser duration when compare to that of smaller ones and has better field performance than small seed.

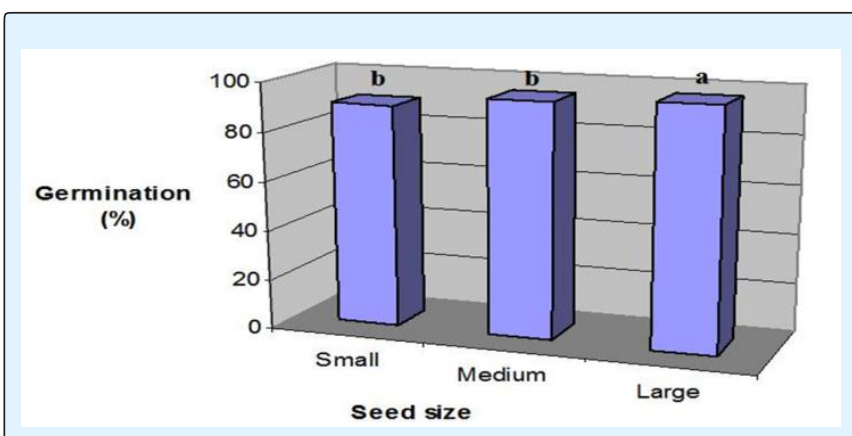

Figure 3: Effect of seed size on germination percentage in wheat [27].

\section{Conclusion}

Wheat (Tritium aestivum L.) is the most important crop and among the major three cereal crops that provides 20 percent of the total energy requirement in human food. It is a major crop contributing importantly to 
the nutrient supply of the global population and has the highest content of protein of all the staple cereals and contains essential minerals, vitamins, and lipids. It shows wide adaptation to diverse agro-ecological conditions and cropping technologies. The productivity of the crop remains low (2.4 tons ha-1) in the Ethiopia as compared to the world average yield (3.19 tons ha-1). The low yield per hectare is attributed to many factors, such as seed source, unavailability of quality seed, use of poor quality seeds, inappropriate seed size and seed rate are some of the factors. Seed source influenced growth and yield during the growing season but the response depended on seed size and variety. Seed quality is very important to optimum growth and yield production in farm which influenced by many factors such as genetic characteristics, viability, germination percent, vigor, moisture content, storage conditions, survival ability and seed health.

High quality seed is important to ensure maximum seed germination and seedling vigor, which is turn is instrumental in achieving maximum yield. poorer quality seeds show low viability, reduced germination and emergence rates, poor tolerance to sub optimal conditions and low seedling growth rates. The seed quality is also reflected in the final growth, maturity of plants, their uniformity and stability of yield. For seed to play a catalytic role, it should reach farmers in a good quality state, i.e. high genetic purity and identity, as well as high physical, physiological and health quality. Seed size is an important physical indicator of seed related to yield, market grade factors and harvest efficiency. Seed size was the trait that was most consistently associated with yields. Seed size was the most consistent seed trait that influenced growth and yield. Grain yield of wheat significantly increased by increasing seed size. Generally, Seed source, seed quality and seed size are major factor that reduce the grain yield of bread wheat, so the growers give attention to use good quality seed and seed size.

\section{References}

1. Shewry PR (2009) Wheat Research. Wheat Journal of Experimental Botany 60(6): 1537-1553.

2. Pena RJ (2007) Current and future trends of wheat quality needs. In: Buck, HT, Nisi JE, Salomon N (Eds.), Wheat production in stressed environments. Springer, pp: 411-424.

3. Farzi A, Bigloo BSM (2010) Evaluation of genetic diversity of wheat lines by for related traits to drought tolerance. The 11th Iranian Congress of Agronomy Science and Plant Breeding, pp: 155-157.
4. Jayne TS, Mason N, Myers R, Ferris J, Mather D, et al. (2010) Patterns and trends in food staples markets in eastern and Southern Africa: toward the identification of priority investments and strategies for developing. Markets and promoting smallholder productivity growth. MSU International Development Working Paper Number 104. East Lansing: Michigan State University.

5. FAOSTAT (Food and Agriculture Organization of the United Nations) (2013) World Crop production data.

6. CSA (Central Statistical Agency) (2014) Report on Area and Crop Production forecast for Major Crops (for private Peasant Holdings 'Meher' season). Addis Ababa, Ethiopia.

7. Rukavin H, Kolak I, Sarcevic H, Satovic Z (2002) Seed size, yield and harvest characterstics of three Croatin spring malting barleys. Bodenkultur 53(1).

8. Tanner D, Sahle G (1993) Weed control research conducted on wheat in Ethiopia. In: Gebre-Mariam H, Tanner DG, Hulluka M (Eds.), Wheat research in Ethiopia: a historical perspective. Addis Ababa, IAR/CIMMYT.

9. Birhanu B (2010) Assessment of Bread Wheat Production, Marketing and Selection of N Efficient Bread Wheat (Tritium aestivum L.) Varieties for Higher Grain Yield and Quality in North Western Ethiopia. MSc. Thesis, Haramaya University, Haramaya, Ethiopia.

10. Kotu B, Verkuijl H, Mwangi W, Tanner D (2000) Adoption of Improved Wheat Technologies in Adaba and DodolaWoredas of the Bale Highlands, Ethiopia. Mexico, D.F. CIMMYT and the Ethiopian Agricultural Research Organization (EARO).

11. World Fact book (2012).

12. Mathewos A, Tewodros M, Yasin G (2012) Participatory on-farm evaluation of improved bread wheat technologies in some districts of southern Ethiopia. J Biol Agri Healthcare 2(4): 85-91.

13. Alemayehu A (2015) Effect of Seed Sources and Rates on Productivity of Bread Wheat (Triticum aestivum L.) Varieties at Kersa, eastern Ethiopia. Haramaya University, Haramaya.

14. Dawit A (2010) The Political Economy of Ethiopian Cereal Seed Systems. Market Liberalization and Decentralization. Addis Ababa, Ethiopia, pp: 223-289 


\section{Journal of Ecology \& Natural Resources}

15. ESSP (Ethiopian Seed Strategies Program) (2006) Ethiopian Seed System Regulation and Stakeholders: 6-8, Addis-Ababa, Ethiopia, pp: 109-115.

16. Hampton JG (2002) What is Seed Quality? Seed Science and Technology. 30: 1-10.

17. Banu S, Duxbury JM, Lauren JG, Meisner C, Slam RI (2004) Wheat seed quality a study on farmer's seed. Paper presented at 4th International Crop Science Congress, Brisbane, Queensland, Australia.

18. Akbar GA, Ghasemipirbalouti M, Najaf AFM, Shahverdi M (2004) Effects of harvesting time on soybeans seed germination and vigor. J Agr 6: 6-18.

19. Molnar I, Vujaković M, Milošević M, Kastori R, Milošev $D$, et al. (2005) Uticaj đubrenjaiplodoredanaži votnusposobnost semenaozimep šenice. Field Vegetable Crop 41: 257-267.

20. Finch -Sevege W E, 2000: Influence of seed quality on crop establishment, growth and yield. In Seed Quality. Basic mechanism and agricultural implications.

21. Dogbe W, Dzomeku IK, Yahaya BS, Siise A, Krofa EO, et al. (2015) Influence of seed quality and soil fertility management on the production of rice. UDS International Journal of Development 2(2): 15-25.

22. Kumar D, Seth R (2004) Seed yield response of fodder cowpea (Vigna unguiculata (L.) Walp) varieties to varying seed rate and seed size. Seed Res 32: 149153.

23. Gan Y, Stobbe EH (1995) Effect of variations in seed size and planting depth on emergence, infertile plants' and grain yield of spring wheat. Can J Plant Sci 75(3): 565-570.

24. Zareian A, Yari L, Hasani F, Ranjbar GH (2013) Field performance of three wheat (Triticum aestivum L.) cultivars in various seed sizes. World App Sci J 16(2): 202-206.

25. Stougaard RN, Xue QW (2004) Spring wheat seed size and seeding rate effects on yield loss due to wild oat (Avena fatua) interference. Weed Sci 52(1): 133-141.

26. Bicer BT (2009) The effect of seed size on yield and yield components of chickpea and lentil. Afr J Biotechnol 8(8): 1482-1487.

27. Hossein AF, Payam M, Kasra M (2011) Effect of seed size on seedling production in wheat. Adv Environ Biol 5(7): 1711-1715.
28. Simmone R, Steege HT, Werger M (2000) Survival and growth in gaps: A case study for tree seedlings of 8 species in the Guyanese tropical rainforest in seed seedlings and gap size matters. Troplenbos-Guyana Programmes, Guyana.

29. Stougaard RN, Xue Q (2005) Quality versus quantity: Spring wheat seed size and seeding rate effects on Avena fatua interference, economic returns and economic thresholds. Weed Res 45(5): 351-360.

30. Lima ER, Santiago AS, Araujo AP, Teixeira MG (2005) Effects of the size of sown seed on growth and yield of common bean cultivars of different seed sizes. Brazil J Plant Physiol 17(3): 273-281.

31. Khurana E, Singh JS (2000) Influence of seed size on seedling growth of Albizia procera under different soil water levels. Ann Bot 86(6): 1185-1192.

32. Stobbe E, Moes J, Gan Y, Ngoma H, Bourgeca L (2008) Seeds, seed vigor and seeding research report. Department of Plant Science, NDSU Agriculture and University Extension, North Dakota, USA.

33. Adejare KO (2010) Effect of seed size and shape on field performance of tropical maize (Zea mays L.) varieties. Project Report, Department of Plant Breeding and Seed Technology, Federal University of Agriculture, Abeokuta, Nigeria.

34. Enayat MR, Bakhshandeh AM, Shoar MD, Ghaineh MH, Saeid KA, et al. (2012) Effect of source and seed size on yield component of corn S.C704 in Khuzestan. Afr J Biotechnol 11(12): 2938-2944.

35. Abdul RS, Sana UB, Shahbaz KB, Baber M, Waseem B, et al. (2014) Influence of Seed Size on Germinability and Grain Yield of Wheat (Triticumaestivum L.)Varieties. J Nat Sci Res 4(23).

36. Elliott RH, Franke C, Rakow GFW (2008) Effects of seed size and seed weight on seedling establishment, vigour and tolerance of Argentine canola (Brassica napus) to flea beetles, Phyllotreta spp. Can J Plant Sci 88(1): 207-217.

37. Dar FA, Gera M, Gera N (2002) Effect of seed grading on germination pattern of some multi-purpose tree species of Jammu Region. Indian For 128(5): 509-512.

38. Adebisi MA, Kehinde TO, Salau AW, Okesola LA, Porbeni JBO, et al. (2013) Influence of different seed size fractions on seed germination, seedling emergence and seed yield characters in tropical 


\section{Journal of Ecology \& Natural Resources}

soybean (Glycine max L. Merrill). Int J Agric Res 8(1): 26-33.

39. Khajeh HM, Powell AA, Bingham IJ (2003) The interaction between salinity stress and seed vigour during germination of soyabean seeds. Seed Sci Technol 31(3): 715-725.

40. Ries SK, Everson EH (1973) Protein content and seed size relationships with seedling vigor of wheat cultivars. Agron J 65(6): 884-886.
41. Cookson WR, Rowarth JS, Sedcole JR (2001) Seed vigour in perennial ryegrass (Lolium perenne L.): Effect and cause. Seed Sci Technol 29(1): 255-270.

42. Gunaga RP, Hareesh TS, Vasudeva R (2007) Effect of fruit size on early seedling vigour and biomass in white dammer (Vateria indica): A vulnerable and economically important tree species of the Western Ghats. J NTFPs 14: 197-200. 